\title{
Zakat Fundraising Strategy: Opportunities and Challenges in Digital Era
}

\section{Mohammad Soleh}

IAIN Salatiga

mohammad.soleh@iainsalatiga.ac.id

\begin{abstract}
This research aimed at providing a new perspective on the fundraising strategy of zakat through its opportunity and challenge approach in the digital era, by analyzing and identifying existing problems in the previous zakat fundraising strategy, as an effort to reduce the gap between the potential and realization of zakat fundraising in Indonesia. This was a literary study by using a qualitative descriptive analysis method based on library research. This research succeeded in finding and identifying the problem of zakat fundraising strategies in zakat institutions, namely; 1) the need to improve organizational governance; 2) institutional strengthening; and 3) seizing opportunities and challenges in the digital era by transforming digital fundraising technology. The findings of this study can be a recommendation in perfecting zakat fundraising strategies to be applied to zakat institutions. This paper also recommends the perpetrators of Islamic philanthropy to work together with the government in formulating various efforts to optimize the fundraising of zakat and its distribution on target.
\end{abstract}

Keywords: zakat; fundraising; strategy; challenges; digital era.

\section{Abstrak}

Penelitian ini bertujuan memberikan perspektif baru tentang strategi fundraising zakat melalui pendekatan peluang dan tantangannya di era digital, dengan menganalisis dan mengidentifikasi masalah yang ada dalam strategi fundraising zakat sebelumnya, sebagai salah satu upaya menekan gap antara potensi dan realisasi penghimpunan dana zakat di Indonesia. Penelitian ini merupakan studi literatur yang menggunakan metode analisa deskriptif kualitatif berbasis kajian kepustakaan (library research). 
Penelitian ini berhasil menemukan dan mengidentifikasi masalah strategi fundraising zakat pada lembaga zakat, yaitu; 1) perlunya memperbaiki tata kelola organisasi; 2) penguatan institusi; dan 3) menangkap peluang dan tantangan di era digital dengan melakukan transformasi teknologi digital fundraising. Hasil temuan penelitian ini dapat menjadi rekomendasi dalam menyempurnakan strategi fundraising zakat untuk diterapkan pada lembaga zakat. Tulisan ini juga merekomendasikan kepada para pelaku filantropi Islam untuk bersinergi bersama-sama dengan pemerintah dalam merumuskan berbagai upaya optimalisasi fundraising zakat dan pendistribusiannya secara tepat sasaran.

Kata Kunci: zakat, fundraising, strategi, tantangan, era digital.

\section{INTRODUCTION}

Indonesia is the country with the largest Muslim population in the world with a population of 209.1 million (Pew Research Center's Forum on Religion and Public Life, 2011) with such a large Muslim population, Indonesia ranks 1 in 10 countries with the largest Muslim population in the world. It is certain that with the largest Muslim population, followed by good economic growth, Indonesia has enormous zakat potential. According to Wibisono (2016), National Amil Zakat Agency (BAZNAS) estimates that the potential for national zakat in 2015 will reach Rp. 286 trillion or 2.4\% of the 2015 Gross Domestic Product (GDP). If using zakat potential is $3.4 \%$ of GDP, the potential for national zakat in 2016 reaches Rp. 442 trillion. This number should have an extraordinary impact on efforts to achieve prosperity and poverty alleviation in Indonesia.

In the last five years, the collection of national zakat has grown by an average of around $20 \%$ per year. In 2016, it is estimated that the national zakat collection achievement will reach around $\mathrm{Rp} 4.4$ trillion (Wibisono, 2016). However, when compared to the zakat potential of $3.4 \%$ of GDP, the realization of zakat collection in 2016 is only $1.0 \%$ of its potential (Canggih, Fikriyah, \& Yasin, 2017). There is a considerable gap between the potential and the collection of zakat funds. In other words, there is a gap that arises when seeing the potential for zakat is greater than the collection of zakat. There are serious problems that must 
be solved in order to be able to suppress the gap between potential and its collection.

So far BAZNAS and Amil Zakat Agency (LAZ) as zakat management organization or Zakat Management Organization(OPZ) has tried to provide services and various programs to facilitate the collection of zakat. However, it is still not optimal to capture the potential of zakat in Indonesia. To follow up the issue of the gap between the potential and the achievements of collecting zakat, it is necessary to evaluate why the zakat fundraising strategy that has been carried out has not been effective. Moreover, in the digital era of the industrial revolution 4.0 which is very dependent on the internet, OPZ must be observant in capturing opportunities and challenges. Utilizing digital technology to get a target market reach that is further and wider in socializing OPZ programs, providing education about zakat and reporting its distribution activities to Mustahiq with full trust, professionalism and transparent. Besides that, OPZ is demanded to be able to understand market behavior (prospective muzakki) to foster trust, interest and willingness to pay zakat (Efendi \& Ferdi, 2019).

Other research related to zakat fundraising strategies or about challenges in the digital age has been carried out, for example: research by Leeflang, Verhoef, Dahlström, \& Freundt (2014) which examines the challenges faced by corporate marketing in the digital era and its solutions; Siregar (2016) research which discusses the problematic fundraising of zakat in a Regional Amil Zakat Agency (Bazda);

Abidah (2016) research about the analysis of fundraising strategies to improve the management of zakat, infaq and Shadaqah at the Amil zakat institution; Kasri \& Putri, (2018) research offering a fundraising method as a technique to optimize the potential of zakat in Indonesia; Nopiardo (2018) research on the strategy of collecting zakat funds at the National Amil Zakat Agency (Baznas) ; Efendi \& Ferdi (2019) research that analyzes the phenomenon of the development of Islamic philanthropy in the digital age with a qualitative approach.

However, so far no research has been found that specifically addresses the fundraising strategy of zakat from the perspective of opportunities and challenges in the digital age. Therefore, this study aims to provide a new perspective on the zakat fundraising strategy through the 
opportunities and challenges approach in the digital era by analyzing and identifying existing problems in zakat fundraising strategies before, as one of the efforts to suppress the gap between the potential and the achievements of zakat collection realization.

\section{METHODOLOGY}

This study is a literature study that uses a qualitative descriptive analysis method based on library research. Qualitative descriptive analysis is an analysis based on the mapping of problems contained in the variables or cases that are being studied and then looking for the correlation point. This correlation can be confirmed, rejected, and balanced based on data and information that has been successfully carried out by researchers. While library research is a research instrument by collecting various kinds of literature both in the form of journals, books, proceedings, working papers, and other data sources that have relevance to the problems in this study.

The stages of activities in analyzing data and documents in this study are: 1) Conducting a preliminary study by examining previous research studies that discuss the fundraising strategy of zakat along with the opportunities and challenges in the digital era; 2) Gathering relevant literature in accordance with the focus of the issues raised as the main theme in this study; 3) Critically analyzing the various sources of literature to get a basic understanding of the correlation between studies and the variables studied; 4) Writing the results of the study based on analytical arguments from various data and literature studies; and 5) Formulating recommendations based on analytical arguments from various data and literature studies.

\section{RESULT AND DISCUSSION}

Zakat is a philanthropy that is well known in the Islamic world. Zakat is one of the pillars of Islam that must be carried out by every Muslim, this Islamic philanthropy by Wibisono (2016) referred to as "spiritual tax", although in some ways between tax and zakat has some differences. Zakat is one of the worship that has a unique and unique style, namely worship with two dimensions at once. First, it has a social dimension. Secondly, zakat has an economic dimension which is certainly very important in 
realizing the welfare of the Ummah. This makes zakat a topic of Islamic philanthropy which is always interesting to be continuously studied by experts, in order to realize a social justice in the life of society at large.

Fundraising activities are the main activities in a zakat institution. Zakat Management Organization (OPZ) positions itself as a mediator between muzakki who pays zakat and mustahiq who receives zakat. Thus OPZ becomes an intermediary for muzakki in fulfilling their obligation to pay zakat, to then be distributed to the mustahiq, in accordance with the provisions set by the Islamic Sharia (Rohim, 2019).

According to Siregar (2016) the cause of the low collection of zakat is that not all regions require the payment of zakat from salaries of civil servants (PNS), State-owned enterprises (BUMN), Regional owned enterprises (BUMD) as well as from the Police, Judiciary and Private institutions. At this time, with the Presidential Instruction Number 3 of 2014 concerning the optimization of zakat collection, in fact the heads of agencies have been able to execute the implementation of the Presidential Instruction. If all agencies can require zakat deductions directly from employee income, then human resources at BAZNAS are no longer needed for fundraising activities sourced from PNS, but can focus on strengthening fundraising of zakat from the private sector and the general public.

However, because not all heads of agencies in the regions require it and submit decisions on where to pay alms to each individual, then like a company, OPZ including the National Amil Zakat Agency (BAZNAS) must also have a fundraising strategy in order to grab the attention of the donor market and maintain their loyalty. OPZ does have its own market, which is the obligatory zakat or Muzakki candidates. However, more than that OPZ must also be able to grow the trust and awareness of the Muzakki to be willing to pay their zakat through OPZ both government and private, not channeling it directly to Mustahiq. This is considered very important for the continuity and sustainability of the OPZ itself (Zumrotun, 2016).

In addition, when Muzakki distributes his own zakat directly to Mustahiq without going through the OPZ, then it is certain that the given zakat will be consumptive which will only fulfill the needs a moment later. Of course this is less educational because it will only make Mustahiq 
always depend on the giving of others. In contrast to OPZ which has a vision, mission and goal to turn Mustahiq into Muzakki by providing various empowerment programs through productive zakat.

The fundraising strategy of zakat is a plan for a process of influencing people who are potential donors / Muzakki to be willing to do good deeds in the form of handing over zakat funds to then be distributed to people in need (Mustahiq) through intermediaries for zakat institutions / OPZ. The process of influence here includes the activities of telling, reminding, encouraging, persuading, and seducing (Nopiardo, 2018; Urselmann, 2018).

In zakat fundraising activities, OPZ must continue to educate, socialize, promote and transfer information so as to create understanding, awareness and needs for prospective donors / Muzakki to be loyal in carrying out activities that have been programmed by OPZ. To get the most out of fundraising in a zakat institution, it requires an appropriate strategy and approach for the sustainability of the next step. Because without proper and accurate fundraising strategies, the funds raised cannot be maximized.

\section{Identification of Zakat Fundraising Problems}

So far, the zakat fundraising strategy that has been applied to almost all Zakat Management Organization(OPZ) can basically be divided into two types of methods, namely direct fundraising and indirect fundraising. In general OPZ uses both of these fundraising methods (directly or indirectly). Because both have advantages and their own goals. The direct fundraising method is needed because without it, Muzakki who are already interested in tithing through OPZ will find it difficult to donate their funds. However, if all forms of fundraising are carried out directly, it will appear to be rigid, limited to only Muzakki candidates who were present at the time of fundraiser promotion and potentially create burnout. Both methods can be used flexibly and all institutions must be good at combining the two methods (Nopiardo, 2018).

In addition to the above methods, BAZNAS makes efforts to increase the number of Muzakki by promoting the formation of Unit Pengelola Zakat (UPZ) in government agencies, dissemination through 
radio media, direct lectures to agencies, leaflets and stickers in city transportation cars (Lestari, Pratiwi, \& Ulfah, 2015a).

The fundraising method of zakat and the program of activities carried out in the conventional ways mentioned above, causes public access to information on zakat management in the midst of this digital era to be very limited. Because the methods adopted have not yet maximized the use of information technology. With information technology, OPZ can disseminate programs with wider and easier access, increasing transparency of activities, so that it is expected to increase public trust in zakat management.

OPZ must improve organizational governance, one of which is to have a database of prospective muzakki because it is absolutely necessary to map the fundraising strategy of zakat and as an effort to find out the behavior and wishes of prospective muzakki so that OPZ can provide satisfaction and foster the trust of muzakki.

One important thing that needs to be followed up immediately by the management of OPZ is the reason why muzakki is reluctant to entrust his zakat funds to OPZ. One of them is the existence of muzakki's desire related to the distribution of zakat which rarely gets a response from OPZ, the desire is simple so that many parties underestimate it. Most of the muzakki want zakat that he entrusted to OPZ can be distributed to mustahiq who live in the neighborhood around the muzakki, so that muzakki feels satisfied if he can see directly with his eyes, how his zakat can help ease the burden of people in need. When this desire of muzakki has never been heard or realized by the OPZ, for technical reasons and so on, then what happens is that muzakki prefers to donate his zakat funds directly to mustahiq in his own neighborhood.

The above problems actually do not need to happen if OPZ management wants to listen, understand and then find a solution. For example the solution that can be offered is to use a distribution system to mustahiq through a recommendation from a "Recommendator". The intended recommendator here is muzakki itself. The process is to collect the mustahiq data recommended by muzakki into the mustahiq database, then survey scheduling is conducted by the survey team from OPZ to ensure that the names of the mustahiq candidates actually meet the requirements to become mustahiq through criteria 8 ashnaf. This is one 
alternative solution that can be done by OPZ in order to foster trust and good relations with muzakki.

Of course if the complaint service is carried out with conventional counseling will be very time-consuming, energy and mind. In this digital era, a modern counseling service can utilize existing information technology. As a system that has been applied to the IPTEKnet Badan Pengkajian dan Penerapan Teknologi (BPPT) which is called "Manajemen Keluhan Mitra Kerjasama" based on Framework Code Igniter and SMS Gateway. This system aims to facilitate cooperation partners in being able to express their complaints and facilitate IPTEKnet staff in managing and following up complaints submitted by the cooperation partners (Okviandini, Nurhayati, \& Windasari, 2014).

We need to know that this fundraising effort is the same as an effort to convince people to buy a product at the company. Therefore, maximizing the marketing function by utilizing information technology is an important thing for OPZ to do in optimizing zakat fundraising. Sometimes social organizations still think that marketing is only for profit alone, whereas marketing is more than just looking for profit, namely marketing also aims to bring up the perception (Cluley, 2016).

Poor perception of zakat institutions will eradicate the trust of muzakki. In addition to the fundraising strategy itself, there are other important factors which, if not addressed immediately, will make the public's perception of OPZ worse, so that the fundraising strategy will never work, no matter how good or perfect the strategy is. According to Lestari, Pratiwi, \& Ulfah (2015) the capacity factor of zakat institutions is a common problem in zakat institutions, these problems have an impact on public trust. Lack of public trust in zakat institutions will cause many muzakki to be reluctant to channel their zakat through OPZ, they would rather donate it themselves to mustahiq.

Other problems found according to Siregar (2016) are: 1) The structure of BAZNAS unemployment is not in accordance with the law; 2) Lack of operational funding support from the APBD / APBN Regency / City Government; 3) Not yet formed a professional BAZNAS organization; 4) Low performance in collecting zakat; 5) Lack of transparency in reporting. 
The big and urgent challenges to be addressed by the OPZ that are currently faced are: strengthening institutions and the use of information technology. In terms of institutional strengthening, organizational governance becomes very important and very urgent to be addressed immediately. Principles in organizational governance include transparency and accountability. If these two things are not corrected immediately, then the trust in muzakki will be lost, if the trust in muzakki is lost, then the problem of the gap between the potential and the collection of zakat funds will never be resolved.

\section{Opportunities and Challenges of Zakat Fundraising in the Digital Era}

Changes in the world are now entering the era of the industrial revolution 4.0 or the fourth world industrial revolution where information technology has become the basis in human life. Everything becomes borderless with unlimited use of computing power and data, because it is influenced by the development of the internet and massive digital technology as the backbone of the movement and connectivity of humans and machines. This era will also disrupt various human activities (Rohida, 2018).

Among the activities of people affected by disruption are human behavior that experiences a shift in finding and receiving information, making decisions and making transactions, which were previously done offline and manually, now shifting to being completely online and digital through the internet network. A survey of penetration and behavior profiles of Indonesian internet users reported by Asosiasi Penyelenggara Jasa Internet Indonesia (APJII, 2018) shows the following results: 


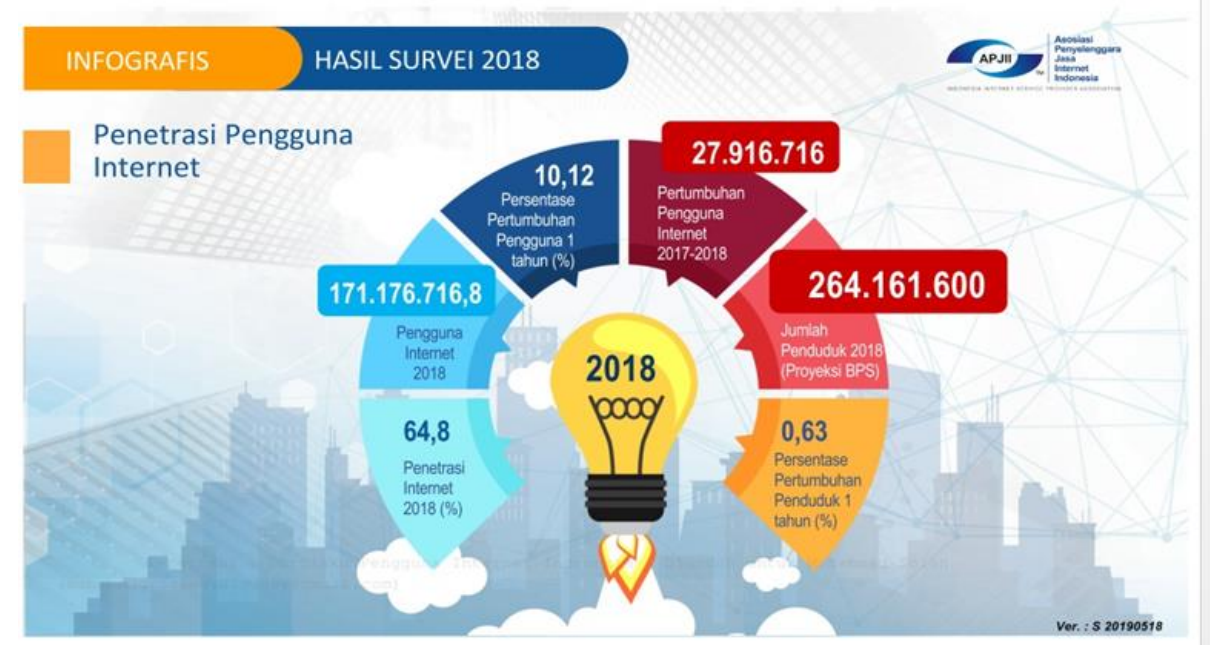

Picture 1: above shows the graph of internet user penetration survey results in Indonesia in 2018 totaling 171.176 .716 people from the total population of Indonesia totaling 264.161.600 inhabitants (BPS, 2018) or as many as $64.8 \%$ of Indonesia's population are internet users. This number is up $10.12 \%$ from the previous year and it is projected that the number will continue to rise in the following years.

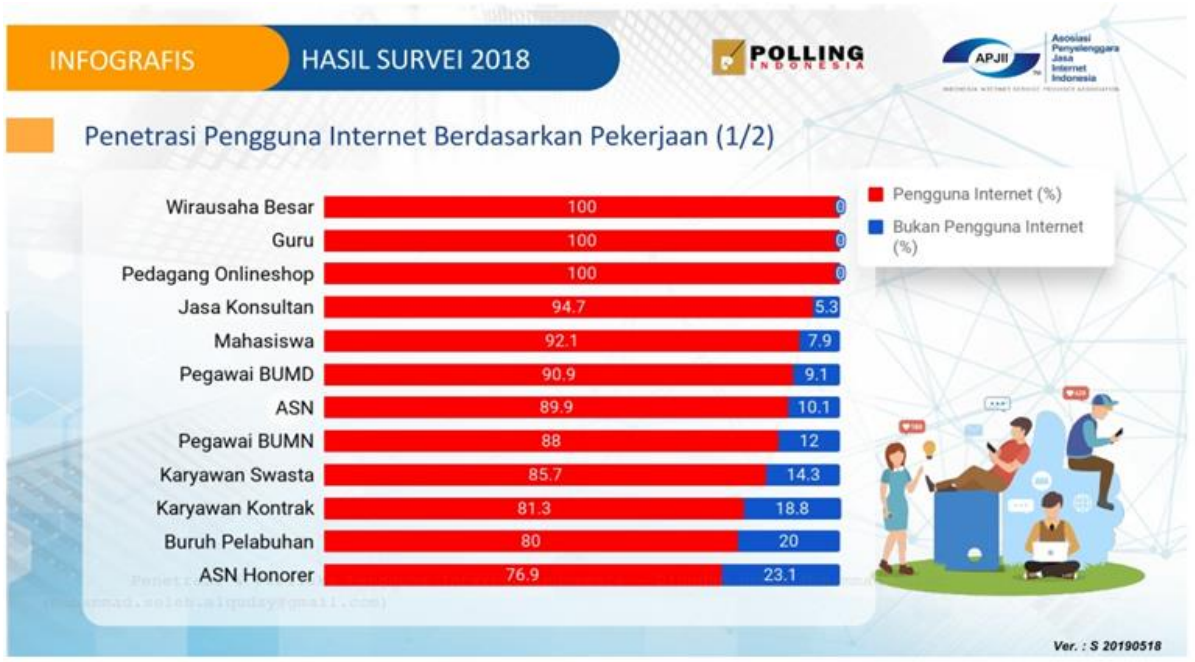

Figure 2: Graph of Internet User Penetration Based on Employment (1) 


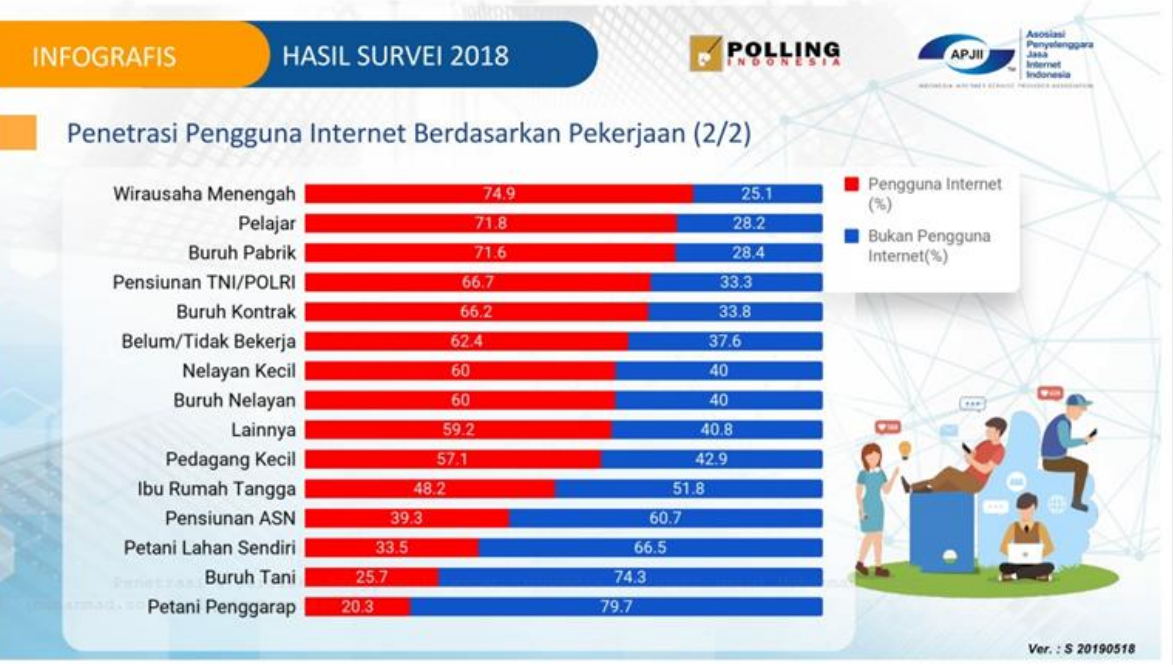

Figure 3: Graph of Internet User Penetration Based on Employment (2)

Furthermore, in pictures $2 \& 3$ above shows the graph of internet user penetration survey results in Indonesia in the same year based on the type of work. The result is that of the 27 types of occupations / professions surveyed, there are 21 types of jobs whose percentage is more than $50 \%$, even up to $100 \%$ of the workers are internet users. Occupying rank 3 in magnitude in a row are; Wirausaha Besar (Big Entrepreneur), Guru / Dosen (Teacher / Lecturer), and Pedagang Onlineshop (Online Trader). The three types of work are $100 \%$ of the workers are active users of the internet.

The shift in human behavior due to disruption in the era of the industrial revolution 4.0 could actually be an opportunity for OPZ to transform by utilizing digital media information technology, so that the socialization of zakat fundraising programs can reach a wider market share through the internet network used by more than 60\% Indonesia's population, especially based on APJII's research (2018), the majority of users are people who have established jobs or upper middle income, so that it is appropriate to be the market share of muzakki candidates. In addition, innovations to facilitate access to information, services, payment of zakat, financial reporting and zakat programs in the form of digital features online need to be immediately applied. 
Utilization of prospective muzakki database is not only to provide information and invite people to want to be muzakki, but also as an effort and means to maintain muzakki loyalty and trust in OPZ. The availability of data on internet users in Indonesia, which includes the classification of age, type of work, economy, and education provided by APJII, will make it easy for OPZ to map in an effort to optimize fundraising through the internet network.

In other words, the solution efforts mentioned above can be recommendations from this paper to OPZ to be able to use the internet not merely to provide convenience of transaction services, but also as an effort to socialize OPZ programs, educate, communicate in both directions can understand what muzakki complains and wants as well as caring for muzakki's trust in order to increase the collection of zakat funds (Efendi \& Ferdi, 2019).

Recent developments in financial technology (fintech) require every sector in business and other sectors to apply the system. This includes the zakat collection sector which will be greatly helped by applying the system. Therefore, to answer the challenges of the people in the digital era like today, with their digital lifestyle, zakat institutions need to transform using the latest technology, in order to collect zakat from muzakki, and of course it will make it easier for muzakki in offering zakat to institutions zakat (Rachman \& Salam, 2018).

\section{Zakat Fundraising Technology Transformation Strategy}

Entering the digital era as it is today, technology is increasingly developing. This rapid development, resulted in significant changes in all lines and aspects. It can be said, if OPZ survives with conventional fundraising mechanisms in this digital era, it is likely that this will not make a better contribution, and even tends to be less effective. Conversely, when OPZ transforms, especially on the fundraising side, namely by utilizing technology and digital media, this will have a positive impact on the socialization program undertaken (Rohim, 2019).

By maximizing technology and digital media, the socialization program carried out by OPZ will be able to cover many things. That way, public access to get information related to zakat in OPZ will be wider. Even the public will get access to information easily. Technological 
developments that occur later, are the effects of disruptive innovation. Rachman \& Salam (2018) defines disruptive innovation as an innovation that has succeeded in changing and transforming an existing system or an established market, with a system structure that emphasizes aspects of ease of access, convenience, and of course lower costs. For muzakki, they will feel this ease in terms of paying their zakat through OPZ.

Need to be understood together, that the rapid development of media as it is today, in essence shows the development of an increasingly advanced and developing era. In plain view, such developments are only felt on the technology side. But more than that, the development that is indicated by technological advances, is a reflection of the development of community culture. Departing from this phenomenon, the OPZ in conducting zakat fundraising must be able to transform from conventional mechanisms and methods, into digital fundraising. Moreover, this phenomenon does not only penetrate the world of adultery specifically, but also covers all aspects of finance that introduce people to the phenomenon of fintech.

Islam as a universal religion, is very open to the dynamics of the development of human civilization. No exception, in terms of technological developments in the economic and financial fields. So zakat, as a ibadah maaliyah, must still be in the corridor of sharia compliance even though applying technology in its application. Related to this, Rachman \& Salam (2018) recommends that in order to apply a management that is in accordance with sharia principles, an OPZ must meet the provisions and standardization on two aspects: first, the technical structure which includes the determination of the contract, administrative costs, and the calculation of zakat. Second, on the side of financial statements that must be in accordance with the rules and standards of sharia financial reporting standards. Furthermore, to strengthen the institution, it needs to be done continuous supervision of sharia, to the development of the system and management of zakat that follows the development of fintech.

Each element and institution related to the development and management of zakat in Indonesia must work together with the government to formulate short-term, medium-term and long-term directives and targets in the management of zakat. If other institutions 
have a blueprint for zakat development, OPZ must also have a blueprint for zakat development. To realize this, ideally the government forms a special institution or ministry that handles the management of zakat funds (Zumrotun, 2016).

If the various challenges of zakat fundraising issues above are not immediately followed up and opportunities for technological transformation in the digital era are not immediately welcomed and properly applied, these challenges and opportunities will turn out to be a serious threat to the survival of the zakat institution. Then the potential is so great with the increasing number of potential muzakki candidates more than $60 \%$ of Indonesia's population as the results of the APJII (2018) survey, and the potential to always increase every year will pass just like that. So that the problem of the gap between the potential and the collection of zakat that has occurred from the past until today, will remain an eternal "Homework" in the history of zakat fundraising in Indonesia.

\section{CONCLUSION}

There is a gap between the potential and the realization of zakat collection in Indonesia. This indicates that there is a problem with the zakat fundraising strategy used by zakat management organization (OPZ). This research succeeded in identifying problems in OPZ zakat fundraising, namely; the need to improve organizational governance and strengthen institutions and capture opportunities and challenges in the digital era by transforming digital fundraising technology. The findings of this study can be recommendations in perfecting the zakat fundraising strategy to be applied to OPZ. This paper also recommends the perpetrators of Islamic philanthropy to work together with the government in formulating various efforts to optimize the fundraising of zakat and its distribution on target.

In this paper, of course there are many shortcomings because research time is limited and there are not many references that discuss fundraising of zakat. But hopefully this article can make a real contribution to zakat institutions, the government, and all parties involved in Islamic philanthropy. 


\section{BIBLIOGRAPHY}

Abidah, A. (STAIN P. (2016). Analisis Strategi Fundraising Terhadap Peningkatan Pengelolaan ZIS pada Lembaga Amil Zakat Kabupaten Ponorogo. Jurnal Kodifikasia, 10(1), 163-189.

APJII. (2018). Penetrasi \& Profil Perilaku Pengguna Internet Indonesia. Apjii. Retrieved from www.apjii.or.id

Canggih, C., Fikriyah, K., \& Yasin, A. (2017). Potensi Dan Realisasi Dana Zakat Indonesia. Al-Uqud : Journal of Islamic Economics, 1(1), 14. https://doi.org/10.26740/jie.v1n1.p14-26

Cluley, R. (2016). The depiction of marketing and marketers in the news media. European Journal of Marketing, 50(5/6), 752-769. https://doi.org/10.1108/EJM-02-2015-0076

Efendi, M. (IAIN S., \& Ferdi, A. (IAIN S. (2019). Islamic Philanthropy Development in Digital Era: New Strategy of Fund Raising and Supervision Program. BISNIS: Jurnal Bisnis Dan Manajemen Islam, 7 Nomor 1,(1), 129-142. Retrieved from http://journal.stainkudus.ac.id/index.php/bisnis/index\%0AIslamic

Kasri, R. A., \& Putri, N. I. S. (2018). Fundraising Strategies to Optimize Zakat Potential in Indonesia: An Exploratory Qualitative Study. AlIqtishad: Jurnal Ilmu Ekonomi Syariah, 10(1), 1-24. https://doi.org/10.15408/aiq.v10i1.6191

Leeflang, P. S. H., Verhoef, P. C., Dahlström, P., \& Freundt, T. (2014). Challenges and solutions for marketing in a digital era. European Management Journal, 32(1), 1-12. https://doi.org/10.1016/j.emj.2013.12.001

Lestari, P., Pratiwi, U., \& Ulfah, P. (2015a). Identifikasi Faktor Organisasional Dalam Pengembangan E-Governance Pada

Organisasi Pengelola Zakat. MIMBAR, Jurnal Sosial Dan Pembangunan, 31(1), 221. https://doi.org/10.29313/mimbar.v31i1.1319

Lestari, P., Pratiwi, U., \& Ulfah, P. (2015b). Identifikasi Faktor Organisasional Dalam Pengembangan E-Governance Pada Zakat Management OrganizationDi Kabupaten Banyumas. MIMBAR, Jurnal Sosial Dan Pembangunan, 31(1), 221. https://doi.org/10.29313/mimbar.v31i1.1319 
Nopiardo, W. (2018). Strategi Fundraising Dana Zakat Pada Baznas Kabupaten Tanah Datar. Jurnal Imara: JURNAL RISET $\begin{array}{lll}\text { EKONOMI ISLAM, } & 1(1),\end{array}$ https://doi.org/10.31958/imara.v1i1.991

Okviandini, D., Nurhayati, O. D., \& Windasari, I. P. (2014). Sistem Manajemen Keluhan Mitra Kerjasama Berbasis Framework Code Igniter dan SMS Gateway. Jurnal Teknologi Dan Sistem Komputer. https://doi.org/10.14710/JTSISKOM.2.1.2014.31-39

Pew Research Center's Forum on Religion and Public Life. (2011). The future of the global muslim population. Retrieved from Pew Research Center website: www.pewforum.org/2011/01/27/thefuture-of-the-global-muslim-population $/ \% 0 \mathrm{~A}$

Rachman, M. A., \& Salam, A. N. (2018). The Reinforcement of Zakat Management through Financial Technology Systems. International Journal of Zakat, 3(1), 57-69.

Rohida, L. (2018). Pengaruh Era Revolusi Industri 4.0 terhadap Kompetensi Sumber Daya Manusia. Jurnal Manajemen Dan Bisnis Indonesia, 6(1), 114-136. https://doi.org/10.31843/jmbi.v6i1.187

Rohim, A. N. (Universitas P. N. "Veteran" J. (2019). Optimalisasi Penghimpunan Zakat Melalui Digital Fundraising. Al-Balagh; Jurnal Dakwah Dan Komunikasi IAIN Surakarta, Vol. 4. No, 59-90. Retrieved from http://ejournal.iainsurakarta.ac.id/al-balagh

Siregar, S. (Pascasarjana U. S. U. (2016). PROBLEMATIKA FUNDRAISING ZAKAT: Studi Kasus Baznas di Sumatera Utara. Jurnal MIQOT, Vol. XL(1), 247-266.

Urselmann, M. (2018). Fundraising-Management. In Fundraising (pp. 471-594). https://doi.org/10.1007/978-3-658-20331-3_6

Wibisono, Y. (Peneliti S. P. F. (2016). Potensi Zakat Nasional : Peluang dan Tantangan Pengelolaan. Pusat Ekonomi Dan Bisnis Syariah (PEBS) FEUI, 8 Desember(1).

Zumrotun, S. (IAIN S. (2016). Peluang, Tantangan, dan Strategi Zakat dalam Pemberdayaan Ekonomi Umat. Jurnal Ahkam, XVI(1), 97104. 